\title{
Antioxidant properties and phenolic profile of the most widely appreciated cultivated berry species: A comparative study
}

Volkan Okatan*

Department of Horticulture, Faculty of Agriculture and Natural Sciences, Uşak University, Usak, Turkey

\begin{abstract}
Berries are in the form of a semi-bush or shrub, soft fleshy, juicy, often small and edible. They are generally in bright colours and may sweet or sour in taste. The present study reports a comparison of the antioxidant properties and phenolic profile of the most consumed berry species, namely redcurrant (Ribes rubrum L.), blackcurrant (Ribes nigrum L.), red raspberry (Rubus idaeus L.), blackberry (Rubus fruticosus L.), gooseberry (Ribes uva-crispa L.) and jostaberry (Ribes $\times$ nidigrolaria Rud. Bauer \& A. Bauer). Results of the present study suggested that the highest antioxidant activity $\left(426.26 \mathrm{mg} \cdot 100 \mathrm{~g}^{-1}\right)$ and anthocyanin contents $\left(226.33 \mathrm{mg} \cdot 100 \mathrm{~g}^{-1}\right)$ are found in Heritage variety of the raspberry species. The highest total phenol content was determined as 1,593.92 $\mathrm{mg}$ of Gallic Acid Equivalents (GAE) in jostaberry fruits. The highest ascorbic acid content was obtained from the Goliath variety of blackcurrant as 2,659.26 mg $\cdot 100 \mathrm{~g}^{-1}$. The highest ellagic acid value was found as $48.30 \mathrm{mg} \cdot 100 \mathrm{~g}^{-1}$ in gooseberry, the highest fumaric and citric acid concentrations were noted from jostaberry fruits as $121.88 \mathrm{mg} \cdot 100 \mathrm{~g}^{-1}$ and $14.84 \mathrm{mg} \cdot 100 \mathrm{~g}^{-1}$, respectively, while the highest malic acid content was determined as $14.70 \mathrm{mg} \cdot 100 \mathrm{~g}^{-1}$ in gooseberry fruits. Our results suggest that berries rich in antioxidant properties and phenolic profile may be an important raw plant material for both the pharmaceutical and food industries.
\end{abstract}

Keywords: antioxidant, berries, blackberries, currant, phenols, raspberry

\section{INTRODUCTION}

The most well-known berries are strawberry, raspberry, blackberry, currant, gooseberry, blueberry, rosehip and jackal plum. Some of the species, such as buffaloberry, serviceberry, cloudberry and farkleberry, have poor economic significance. They are located in forest areas or grown as an ornamental plant. However, due to the scientific confirmation of their contribution to human health, the wild-seen species began to be cultivated (Okatan, 2018). The fruits of different berries (i.e. strawberry, currants, blueberries, raspberry, gooseberry, jostaberry, etc.) look similar in terms of fruit characteristics (mostly aggregate fruit), however, the trees have significant differences in terms of morphology, environmental requirements and cultivation techniques. Therefore, the cultivation of different berries together helps to increase the biodiversity and sustainability of agricultural plantations.

Berries are very important among other fruits due to their unique colour, taste and smell, rich vitamin and mineral contents and a wide variety of uses in the food industry. They can be cultivated in regions at extreme conditions where many other fruit species cannot grow. They show a wide distribution in Asia and Europe to the borders of the North Pole, covering the Caucasus and Iran in the South, and all Mediterranean countries. Rich diversification of species is found in the North American continent, especially in the USA and Canada (Okatan and Çolak, 2019; Zheng et al., 2019).

In terms of human health, vitamins $\mathrm{E}$ and $\mathrm{C}$, phenolic substances and organic acids are prominent due to 
their antioxidant properties. High antioxidant capacity of berries is due to phenolic substances, especially anthocyanins rather than ascorbic acid (Gündeşli et al., 2019). The human energy demands can be easily stated with the rapid absorption of soluble sugars contained in the berry fruits. Berry species can be consumed fresh or processed. Dark ones, including blackcurrants, chokeberry and blackberry, are known to contain anticarcinogenic substances (Borges et al., 2010; Pereira et al., 2018). Leaves of berry species contain tannins, flavones, vitamin $\mathrm{C}$, organic acids and sugars. They are also used in tonic, diuretic, wound therapy and diabetes. In addition, they are used in mouthwash for gums, tonsils and throat infections. Berry fruits are astringents and are used internally and in mouthwash (Şar, 2011; Okatan, 2018). Organic acids are easily absorbed by the human digestive system bringing such effects as a strong antioxidant, anti-bacterial and anti-viral activities, the ability to inhibit mutation on DNA, anti-carcinogen and the ability to prevent some types of cancer. In addition, organic acids show strong toxin cleansing and anti-heart attack features (Boehning et al., 2018).

It is obvious that the chemical composition of different berry species may differ from each other. However, it is good to compare the level of basic compounds from plants of one location to underline these differences and to point the most interesting and promising species. Due to the previously described properties of the berry species, the present work highlights differentiation of fruits' antioxidant potential and phytochemical composition, namely total phenol, antioxidant, anthocyanin, ascorbic acid, major phenolic compounds and organic acid contents in redcurrant, blackcurrant, raspberry, blackberry, gooseberry and jostaberry in Turkey.

\section{MATERIALS AND METHODS}

\section{Fruit materials}

The fruit materials of the present study were harvested from a commercial orchard found in Aksu Village of Kestel District located in Bursa Province in June 2019. Rovada variety for redcurrant, Goliath variety for blackcurrant, Heritage variety for raspberry, wild forms of blackberry, gooseberry and jostaberry were used in this study as plant materials. All plant materials were 7 years old and fruits were harvested from five different plants for each species. The study area is one of the Turkey's most significant agricultural areas and is located at $40^{\circ} 09^{\prime} 56.18^{\prime \prime} \mathrm{N}$ and $29^{\circ} 17^{\prime} 58.25^{\prime \prime} \mathrm{E}$. Harvested fruits were immediately brought to the Laboratory of Çukurova University for chemical analyses. The analyses were done in three replicates and each replicate consisted of $200 \mathrm{~g}$ of fruits.

\section{Determination of total phenolic content}

The determination of the phenolic content of the fruits was assessed by the spectrophotometric method according to the Folin-Ciocalteu colorimetry (Li et al.,
2007). Briefly, $60 \mathrm{~mL}$ of pure water was added with $1 \mathrm{~mL}$ of fruit extracts. Then, $5 \mathrm{~mL}$ of Folin-Ciocalteu ready solution was added and mixed well. After $7.5 \mathrm{~min}$, sodium carbonate solution ( $15 \mathrm{~mL}$ of $20 \%$ ) was added to the mixture and the volume of the solutions was mixed to $100 \mathrm{~mL}$ and stirred. After centrifugation $(15,000 \mathrm{~g}$, for $10 \mathrm{~min}$ at $25^{\circ} \mathrm{C}$ ), final solutions were stored in the dark at $25^{\circ} \mathrm{C}$ for $2 \mathrm{~h}$. Hereafter, the absorbance of the solutions was read at $750 \mathrm{~nm}$ by a spectrophotometer. Total phenol amounts were evaluated from the calibration curve obtained with gallic acid and values to be equivalent to milligrams of gallic acid per gram (mg GAE $\cdot \mathrm{g}^{-1}$ dry weight (DW)) (Li et al., 2007).

\section{Antioxidant activity}

The antioxidant capacity of the fruit extract as scavenging activity was assessed by the method described by Re et al. (1999). $\mathrm{ABTS}^{+}$was generated by the reaction of $7 \mathrm{mM}$ aqueous solution of 2,2'-azinobis(3-ethylbenzthiazoline-6-sulfonic acid (ABTS) with $2.45 \mathrm{mM}$ aqueous solution of potassium persulphate. This solution was then kept in dark condition for $16 \mathrm{~h}$. Then, $90 \%$ methanol was used to dilute the $\mathrm{ABTS}^{+}$solution to an absorbance of $0.70 \pm 0.02$ at $734 \mathrm{~nm}$ and equilibrated at $30^{\circ} \mathrm{C}$. Next, $2 \mathrm{~mL}$ of $\mathrm{ABTS}^{+}$was mixed with $20 \mu \mathrm{L}$ of extracts, and $90 \%$ methanol was used as blank for the spectrophotometric measurements. The absorbance was recorded at $734 \mathrm{~nm}$ after $6 \mathrm{~min}$ at $25^{\circ} \mathrm{C}$. The results were expressed as micromoles of Trolox (TE) per gram dry weight sample ( $\mu$ mol Trolox Equivalent Antioxidant Capacity $\left.\cdot \mathrm{g}^{-1} \mathrm{DW}\right)$.

\section{Determining total anthocyanin}

The total anthocyanin contents of fruit samples were calculated by using the absorbance values taken by spectrophotometer at different $\mathrm{pH}$ ranges according to the method suggested by Giusti and Wrolstad (2001). For the measurement of the diluted extracts, $\mathrm{pH} 1.0$ (hydrochloric acid-potassium chloride) and $\mathrm{pH} 4.5$ buffer solutions were prepared and the absorbance values were measured at 531 and $700 \mathrm{~nm}$. The total anthocyanin content (molar extinction coefficient of 28,000, cyanidin-3-glucoside) and absorbance [(A531A700) $\mathrm{pH}$ 1.0-(A531-A700) $\mathrm{pH} 4$.5] were calculated for milligrams per $100 \mathrm{~g}$ fresh weight.

\section{Analysis of ascorbic acid}

Ascorbic acid contents of the fruit samples were determined with high-performance liquid chromatography (HPLC) method proposed by Cemeroglu (2007) and Geçer et al. (2016). Briefly, $5 \mathrm{~mL}$ of fruit extracts were mixed with $2.5 \%(\mathrm{w} / \mathrm{v})$ metaphosphoric acid (Sigma, $\mathrm{M} 6285,33.5 \%$ ) and then centrifuged at 5,500 rpm for $15 \mathrm{~min}$ at $4^{\circ} \mathrm{C}$. Then, $0.5 \mathrm{~mL}$ solution was raised to $2.5 \mathrm{~mL}(\mathrm{w} / \mathrm{v})$ with metaphosphoric acid. The supernatant was then filtered through a 0.45 PTm PTFE syringe filter (Phenomenex, UK). A C18 column (Phenomenex Luna $\mathrm{C} 18,250 \mathrm{~mm} \times 4.60 \mathrm{~mm}, 5 \mathrm{~mm}$ ) was used at $25^{\circ} \mathrm{C}$ to identify ascorbic acid. 


\section{Major phenolic compounds and organic acids}

Phenolic acids of the fruit samples were determined via the method of Rodriguez-Delgado et al. (2001). For this purpose, fruit samples were blended with pure water (1:1). Then, the mixture was centrifuged for $15 \mathrm{~min}$ at $15,000 \mathrm{rpm}$. The isolation of phenolic acids was carried out with an Agilent 1260 series HPLC system equipped with on-line degasser (G 1322A), quat pump (G 1311A),

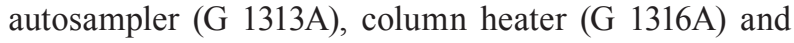
UV detector ( $G$ 1315A). Organic acid composition of the fruits was then determined with the methods described by Bevilacqua and Califano (1989) and Geçer et al. (2016) with minor modifications. Extract of fruits was obtained by crushing the fruits in cheesecloth. The $0.009 \mathrm{~N} \mathrm{H}_{2} \mathrm{SO}_{4}$ was then homogenised with shaker for $1 \mathrm{~h}$. The mixture was then centrifuged at $15,000 \mathrm{rpm}$ for $15 \mathrm{~min}$ and the supernatants were filtered twice (one by a $0.45 \mu \mathrm{m}$ membrane filter and second by a SEP-PAK C18 cartridge). Organic acid readings were performed by HPLC using the Aminex column at 214 and $280 \mathrm{~nm}$ wavelengths.

\section{Statistical analysis}

Raw data of the experiments were subjected to the analysis of variance and the mean separation was performed with Tukey's HSD test at $p<0.05$. Furthermore, the 'FactoMineR' and 'factoextra' package of $R$ were used to perform biplot principal components analysis (PCA) analysis.

\section{RESULTS AND DISCUSSIONS}

Total phenolic contents, antioxidant activity, anthocyanin and ascorbic acid contents of the berry species were found to significantly differ at $p<0.05$ (Table 1). The highest total phenol value was obtained in jostaberry fruits. The lowest total phenol value was obtained in redcurrant fruits. The highest antioxidant level was obtained in blackberry fruits, while the lowest value was obtained in redcurrant fruits. The highest anthocyanin value was obtained in blackberry, while the lowest value was obtained in redcurrant fruits. The highest value of ascorbic acid was found in blackcurrant fruits. The lowest value of ascorbic acid was obtained in raspberry fruits.
In a previous study, Okatan (2016) reported that the total phenolic content of redcurrants and blackcurrants varied between 5.68 and $10.30 \mathrm{mg} \mathrm{GAE} \cdot 100 \mathrm{~g}^{-1} \mathrm{FW}$ and 5.27 and $17.17 \mathrm{mg} \mathrm{GAE} \cdot 100 \mathrm{~g}^{-1} \mathrm{FW}$, respectively. Researchers previously determined that the antioxidant content of redcurrants is between 12.67 and $29.29 \mathrm{mg} \cdot 100 \mathrm{~g}^{-1} \mathrm{FW}$ (Villano et al., 2007; Aneta et al., 2013). Anthocyanin value of redcurrants was previously found as $7.5 \mathrm{mg} \cdot 100 \mathrm{~g}^{-1} \mathrm{FW}$ (Chiang etal., 2013). In another study, the ascorbic acid contents of the redcurrants were reported to vary between 35.41 and $1,410.60 \mathrm{mg} \cdot 100 \mathrm{~g}^{-1}$ FW (Pantelidis et al., 2007; Aneta et al., 2013; Okatan, 2016). Similarly, Mikulic-Petkovsek et al. (2012) found that the antioxidant activity of blackcurrants was $73.55 \mathrm{mg} \cdot 100 \mathrm{~g}^{-1} \mathrm{FW}$. In another study, Rubinskiene et al. (2005) determined the value of anthocyanin content between 14.65 and $15.42 \mathrm{mg} \cdot 100 \mathrm{~g}^{-1}$. In previous studies, researchers determined ascorbic acid values of blackcurrants between 52.97 and 2,779.30 mg $\cdot 100 \mathrm{~g}^{-1}$ FW (Gerçekçioğlu et al., 2009; Okatan, 2016). Total phenolic acids were found between 113.73 and $1,822 \mathrm{mg}$ $\mathrm{GAE} \cdot 100 \mathrm{~g}^{-1} \mathrm{FW}$ in raspberries, between 48.9 and $690.2 \mathrm{mg} \mathrm{GAE} \cdot 100 \mathrm{~g}^{-1} \mathrm{FW}$ in blackberries and between 290 and 2,611 mg GAE $\cdot 100 \mathrm{~g}^{-1} \mathrm{FW}$ in gooseberries (Proteggente et al., 2002; Wada and Ou, 2002; Wang and Lin, 2002; Pantelidis et al., 2007; Giovanelli et al., 2012). In other studies, antioxidant activity was found in line with the findings of the present study in fruits of raspberry, blackberry and gooseberry (Wang and Lin, 2002; Barros et al., 2010; Bobinaitè et al., 2012; LaczkóZöldi et al., 2018; Chanyotha et al., 2019). Researchers determined the values of anthocyanin in raspberry 15.1 $\left.608.24 \mathrm{mg} \cdot 100 \mathrm{~g}^{-1} \mathrm{FW}\right)$, blackberry (35.1-230.74 mg $\left.100 \cdot \mathrm{g}^{-1} \mathrm{FW}\right)$ and gooseberry $\left(1.3-152.2 \mathrm{mg} \cdot 100 \mathrm{~g}^{-1}\right)$ among different amounts (Laleh et al., 2006; Buřičová et al., 2011; Narváez-Cuenca et al., 2014; KosteckaGugała et al., 2015). The main reason for the differences between this study and other studies is due to different ecological conditions.

The major phenolic acid compounds were remarkably differentiated in all the berry species at a statistically important level, $p<0.05$ (Table 2). Rutin value was determined as the highest in jostaberry fruits, and the lowest value was found in redcurrant fruits. Catechin values were found in fruits of blackberry, jostaberry,

Table 1. Comparison of some of the chemical compounds in different berries

\begin{tabular}{|c|c|c|c|c|}
\hline $\begin{array}{l}\text { Berries species } \\
\text { (cultivar) }\end{array}$ & $\begin{array}{c}\text { Total phenol } \\
\left(\mathrm{mg} \mathrm{GAE} \cdot 100 \mathrm{~g}^{-1} \mathrm{FW}\right)\end{array}$ & $\begin{array}{c}\text { Antioxidant } \\
\left(\mathrm{mg} \cdot 100 \mathrm{~g}^{-1} \mathrm{FW}\right)\end{array}$ & $\begin{array}{c}\text { Anthocyanin } \\
\left(\mathrm{mg} \cdot 100 \mathrm{~g}^{-1} \mathrm{FW}\right)\end{array}$ & $\begin{array}{c}\text { Ascorbic acid } \\
\left(\mathrm{mg} \cdot 100 \mathrm{~g}^{-1} \mathrm{FW}\right)\end{array}$ \\
\hline Redcurrant (Rovada) & $8.45 \mathrm{e}$ & $24.41 \mathrm{f}$ & $8.70 \mathrm{e}$ & $1,326.46 \mathrm{~b}$ \\
\hline $\begin{array}{l}\text { Blackcurrant } \\
\text { (Goliath) }\end{array}$ & $11.36 \mathrm{e}$ & $74.43 \mathrm{~d}$ & $17.59 \mathrm{e}$ & $2,659.26 \mathrm{a}$ \\
\hline Raspberry (Heritage) & $735.03 \mathrm{c}$ & $129.25 \mathrm{~b}$ & $176.11 \mathrm{~b}$ & $32.26 \mathrm{f}$ \\
\hline $\begin{array}{l}\text { Blackberry (Wild } \\
\text { plants) }\end{array}$ & $518.66 \mathrm{~d}$ & $426.26 \mathrm{a}$ & $226.33 \mathrm{a}$ & $67.05 \mathrm{e}$ \\
\hline Gooseberry & $1,223.71 \mathrm{~b}$ & $72.23 \mathrm{e}$ & $84.61 \mathrm{~d}$ & $157.91 \mathrm{~d}$ \\
\hline Jostaberry & $1,593.92 \mathrm{a}$ & $125.49 \mathrm{c}$ & $114.80 \mathrm{c}$ & $451.66 \mathrm{c}$ \\
\hline
\end{tabular}

Values followed by the same letter or letters within the same column are not significantly different at $p<0.05$ (Tukey's HSD). 
gooseberry, raspberry, blackcurrant and redcurrant. Chlorogenic acid was found the highest in blackcurrant fruits. Quercetin was found the highest in blackberries, and the lowest value was determined in redcurrant fruits.

Liao et al. (2015) analysed the effect of anthocyanins on the colour of 'Schisandra Chinensis' grape with multiple regression analysis between colour parameters and anthocyanin components and found that rutin is the main cause of change in fruit colour. In other previous studies with blackcurrants, rutin values ranged between 15.71 and $35.41 \mathrm{mg} \cdot 100 \mathrm{~g}^{-1} \mathrm{FW}$, catechin value was reported to be $10.24 \mathrm{mg} \cdot 100 \mathrm{~g}^{-1} \mathrm{FW}$, chlorogenic acid value was reported between 18.35 and $65.49 \mathrm{mg} \cdot 100 \mathrm{~g}^{-1}$ $\mathrm{FW}$ and quercetin value was noted to be between 1.50 and $2.20 \mathrm{mg} \cdot 100 \mathrm{~g}^{-1} \mathrm{FW}$. In the same study for redcurrants, rutin values ranged between 7.23 and $18.52 \mathrm{mg} \cdot 100 \mathrm{~g}^{-1}$ $\mathrm{FW}$, catechin value $7.09 \mathrm{mg} \cdot 100 \mathrm{~g}^{-1} \mathrm{FW}$, chlorogenic acid value $2.38 \mathrm{mg} \cdot 100 \mathrm{~g}^{-1}$ and quercetin value between 2.01 and $2.29 \mathrm{mg} \cdot 100 \mathrm{~g}^{-1}$ (Okatan, 2016). A researcher found quercetin value as 6.32 and rutin value as 15.73 in gooseberry fruits (Chiang et al., 2013). In other studies, rutin contents ranged between 0.97 and $22.77 \mathrm{mg} \cdot 100 \mathrm{~g}^{-1} \mathrm{FW}$ and ferulic acid contents between 0.389 and $2.75 \mathrm{mg} \cdot 100 \mathrm{~g}^{-1}$ in blackberry fruits (Gudej and Tomczyk, 2004; Buřičová et al., 2011; Zia-Ul-Haq et al., 2014; Gundoğdu et al., 2016). The differences in the results are thought to be due to differences in plants, climatic conditions and different ecologies.

The organic acid contents were remarkably differentiated in all the berry species at a statistically important level, $p<0.05$ (Table 3). Ellagic acid values of species were determined in gooseberry, jostaberry, blackberry, raspberry, blackcurrant and redcurrant fruits. Fumaric acid values of berries were found the highest in fruits of jostaberry. Fumaric acid values of blackberry, gooseberry and raspberry were found the same in statistical analysis. The lowest fumaric acid value was determined in redcurrant fruits. The highest malic acid value was obtained in gooseberry fruits and the lowest value was found in raspberry fruits.

In recent years, it has been found that the presence of ellagic acid is significant in berries. The types and values of ellagic acid calculated according to the weight of $1 \mathrm{~g}$ dry fruit are as follows: red raspberry $1.50 \mathrm{mg}$, strawberry $0.63 \mathrm{mg}$, walnut $0.59 \mathrm{mg}$, pecan $0.33 \mathrm{mg}$ and cranberry $0.12 \mathrm{mg}$ (Daniel et al., 1989). Researchers found ellagic acid values between 7.7 and $19.7 \mathrm{mg} \cdot 100 \mathrm{~g}^{-1}$, catechin values between 6.5 and $42.43 \mathrm{mg} \cdot 100 \mathrm{~g}^{-1}$, gallic acid between 3.00 and $14.6 \mathrm{mg} \cdot 100 \mathrm{~g}^{-1}$ and ferulic acid values between 1.00 and $4.90 \mathrm{mg} \cdot 100 \mathrm{~g}^{-1}$ in raspberry fruits (Pantelidis et al., 2007; Pelc et al., 2009; Gulcin et al., 2011; Gevrenova et al., 2013; Adina et al., 2017). In other studies, catechin contents ranged between 111.60 and $438.97 \mathrm{mg} \cdot 100 \mathrm{~g}^{-1}$, ellagic acid contents between 10.61 and $51.51 \mathrm{mg} \cdot 100 \mathrm{~g}^{-1}$, gallic acid contents between 2.20 and $9.43 \mathrm{mg} \cdot 100 \mathrm{~g}^{-1}$ and caffeic acid contents between 1.16 and $12.90 \mathrm{mg} \cdot 100 \mathrm{~g}^{-1}$ in blackberry fruits (Gudej and Tomczyk, 2004; Buřičová et al., 2011; ZiaU1-Haq et al., 2014; Gundoğdu et al., 2016). Caffeic acid value was determined as $2.22 \mathrm{mg} \cdot 100 \mathrm{~g}^{-1}$, kaempferol value as $28.98 \mathrm{mg} \cdot 100 \mathrm{~g}^{-1}$ and $p$-coumaric acid value as $6.99 \mathrm{mg} \cdot 100 \mathrm{~g}^{-1}$ in gooseberry fruits (Chiang et al., 2013). Research has indicated that bioactive values of berries are affected by soil structure, climatic factors, genetic factors and climate. While some results of this study are in agreement with the findings of other researchers, some results are not similar. The differences are thought to be due to different ecological conditions, different harvest times and genetic differences.

The PCA biplot analysis made it possible to evaluate the berry species in terms of the all tested biochemical

Table 2. Comparison of the major phenolic acid compounds in different berries $\left(\mathrm{mg} \cdot 100 \mathrm{~g}^{-1} \mathrm{FW}\right)$

\begin{tabular}{lcccc}
\hline Species (cultivar) & Rutin & Catechin & Chlorogenic acid & Quercetin \\
\hline Redcurrant (Rovada) & $13.46 \mathrm{e}$ & $7.62 \mathrm{f}$ & $2.24 \mathrm{f}$ & $2.17 \mathrm{e}$ \\
Blackcurrant (Goliath) & $15.59 \mathrm{~d}$ & $11.37 \mathrm{e}$ & $56.77 \mathrm{a}$ & $2.47 \mathrm{e}$ \\
Raspberry (Heritage) & $18.32 \mathrm{~b}$ & $43.15 \mathrm{~d}$ & $11.71 \mathrm{e}$ & $4.16 \mathrm{~d}$ \\
Blackberry (Wild plants) & $17.19 \mathrm{c}$ & $327.90 \mathrm{a}$ & $22.57 \mathrm{~d}$ & $8.46 \mathrm{a}$ \\
Gooseberry & $15.53 \mathrm{~d}$ & $124.64 \mathrm{c}$ & $35.20 \mathrm{c}$ & $6.16 \mathrm{c}$ \\
Jostaberry & $22.29 \mathrm{a}$ & $164.64 \mathrm{~b}$ & $42.56 \mathrm{~b}$ & $7.30 \mathrm{~b}$ \\
\hline
\end{tabular}

Values followed by the same letter or letters within the same column are not significantly different at $p<0.05$ (Tukey's HSD).

Table 3. Comparison of the organic acids contents in investigated berries ( $\left.\mathrm{mg} \cdot 100 \mathrm{~g}^{-1} \mathrm{FW}\right)$

\begin{tabular}{|c|c|c|c|c|}
\hline Species & Ellagic acid & Fumaric acid & Citric acid & Malic acid \\
\hline Redcurrant (Rovada) & $4.85 \mathrm{e}$ & $7.29 \mathrm{~d}$ & $13.44 \mathrm{~b}$ & $2.55 \mathrm{~d}$ \\
\hline Blackcurrant (Goliath) & $5.76 \mathrm{e}$ & $8.98 \mathrm{c}$ & $12.13 \mathrm{c}$ & $7.14 \mathrm{c}$ \\
\hline Raspberry (Heritage) & $11.35 \mathrm{~d}$ & $32.47 \mathrm{~b}$ & $9.60 \mathrm{~d}$ & $0.98 \mathrm{e}$ \\
\hline Blackberry (Wild plants) & $37.43 \mathrm{c}$ & $33.53 \mathrm{~b}$ & $5.27 \mathrm{e}$ & $2.05 \mathrm{~d}$ \\
\hline Gooseberry & $48.30 \mathrm{a}$ & $33.35 \mathrm{~b}$ & $9.31 \mathrm{~d}$ & $14.70 \mathrm{a}$ \\
\hline Jostaberry & $39.47 \mathrm{~b}$ & $121.88 \mathrm{a}$ & $14.84 \mathrm{a}$ & $13.50 \mathrm{~b}$ \\
\hline
\end{tabular}

Values followed by the same letter or letters within the same column are not significantly different at $p<0.05$ (Tukey's HSD). 
compounds. It is clear from Figure 1 that the gooseberry and jostaberry species have the highest concentrations of chlorogenic, malic acid, fumaric acid, total phenolic, rutin and ellagic acid. Blackberries (wild plants) are found to be high in quercetin, catechin and anthocyanins and showed the highest antioxidant activity. The blackcurrant ('Goliath') species was found to be superior in terms of ascorbic acid concentration while all other biochemical compounds were lowest in this species. The other two species of the present study, the redcurrant ('Rovada') and raspberry ('Heritage') are found to be the poorest sources of the biochemical compounds. The results of PCA analysis also made it possible to correlate the biochemical compounds. According to the results, some of the chemicals were found to have strong positive correlations (chlorogenic vs. malic acid; fumaric acid vs. TP (Total Phenol); fumaric acid vs. rutin; TP vs. rutin; rutin vs. ellagic acid; ellagic acid vs. quercetin; quercetin vs. catechin; catechin vs. ACNs; ACNs vs. AA) and some strong negative correlations (AsA (Ascorbic Acid) vs. AA; AsA vs. ACNs; AsA vs. Catechin; AsA vs. quercetin; citric acid vs. AA; citric acid vs. ANCs (Acid Neutralizing Capacity); citric acid vs. catechin) where some of them are not correlated (AsA vs. chlorogenic; AsA vs. malic acid; citric acid vs. fumaric acid; citric acid vs. TP; citric acid vs. rutin; chlorogenic vs. quercetin; malic acid vs. quercetin; fumaric acid vs. catechin; TP vs. ACNS; TP vs. AA; rutin vs. ACNs; rutin vs. AA). The highest correlation was obtained among the total phenolic contents with fumaric acid, rutin and ellagic acid. Moreover, malic acid and chlorogenic acid were also noted to have a strong correlation. The anthocyanin content, as a source of antioxidant activity, was also strongly correlated with antioxidant activity.

\section{CONCLUSION}

In this study, chemical compounds of the berry species were determined, and nutritional values and importance of berry species for human health were found due to its large amount of bioactive components. Jostaberry fruits have the highest antioxidant activity among the fruit species studied. The highest ascorbic acid content was found in blackcurrant ('Goliath') fruits. The highest value of rutin was found in jostaberry. The highest values of ellagic acid and malic acid were determined in gooseberry fruits. Berries are very valuable fruits and they contain high levels of bioactive substances. Therefore, the cultivation of these fruit species should be expanded. It is noteworthy that gooseberry and jostaberry are rich in organic acids.

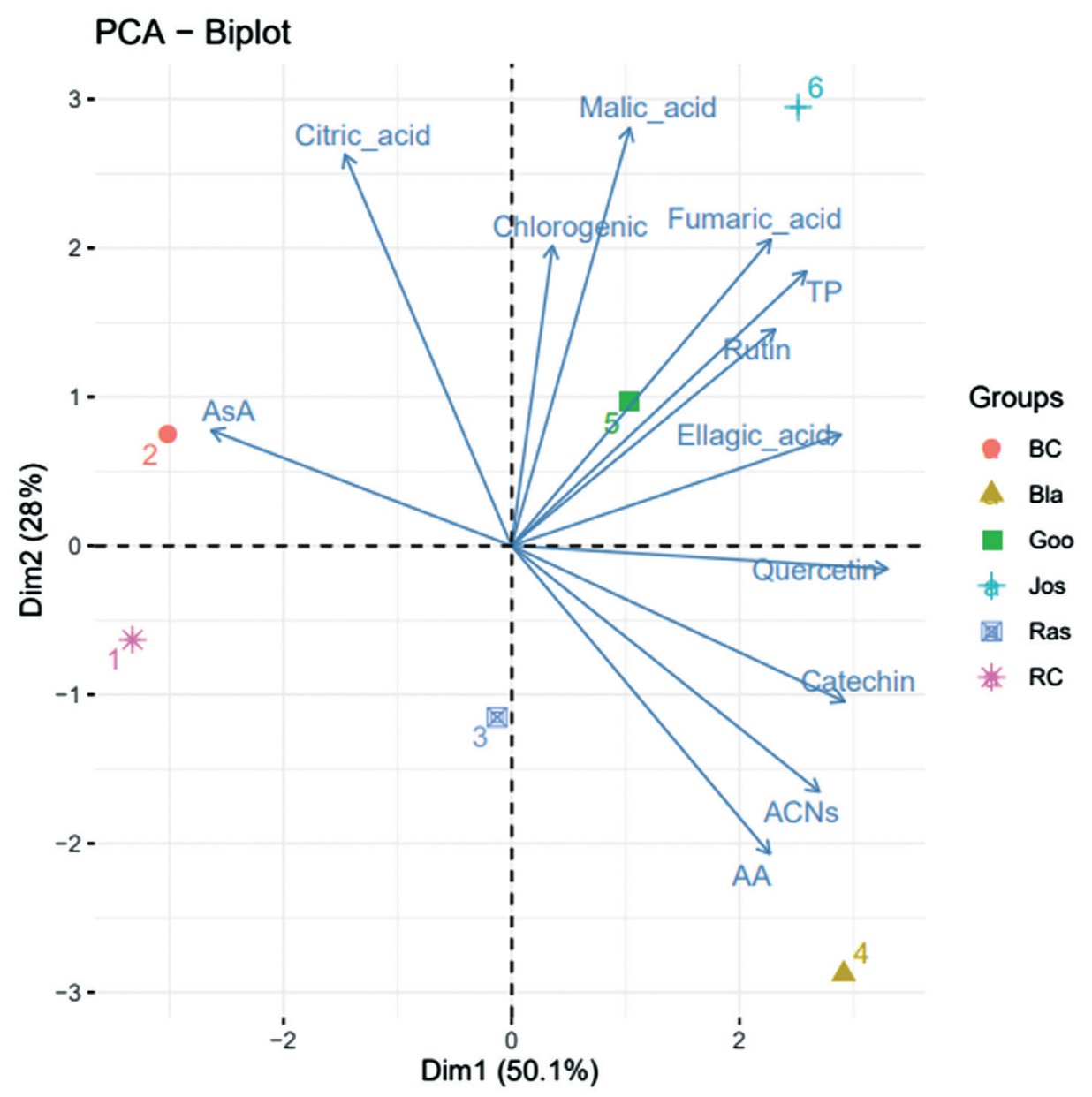

Figure 1. PCA biplot analysis of the berry species and chemical compounds. 


\section{ACKNOWLEDGEMENTS}

I am very grateful to Recep Karagöz (owner of the orchard) for permission for the collection of fruit samples and Dr Muhammet Ali Gundesli for helping me with chemical analysis in the laboratory.

\section{CONFLICT OF INTEREST}

The author declares that no conflict of interest exists.

\section{REFERENCES}

Adina, F., Cecilia, G., Felicia, G., Carmen, D., and Ovidiu, T. (2017). Identification and quantification of phenolic compounds from red currant (Ribes rubrum L.) and raspberries (Rubus idaeus L.). International Journal of Pharmacology, Phytochemistry and Ethnomedicine, 6, 30-37.

Aneta, W., Jan, O., Magdalena, M., and Joanna, W., (2013). Phenolic profile, antioxidant and antiproliferative activity of black and red currants (Ribes spp.) from organic and conventional cultivation. International Journal of Food Science \& Technology, 48(4), 715-726.

Barros, L., Carvalho, A. M., Morais, J. S., And Ferreira, I. C. F. R., (2010). Strawberry-tree, blackthorn and rose fruits: Detailed characterization in nutrients and phytochemicals with antioxidant properties. Food Chemistry, 120, 247-254.

Bevilacqua, A. E., And Califano, A. N. (1989). Determination of organic acids in dairy products by high performance liquid chromatography. Journal of Food Science, 54(4), 1076-1076.

Bobinaité, R., Vikelis, P., and Rimantas-Vensutonis, P. (2012). Variation of total phenolics, anthocyanins, ellagic acid and radical scavenging capacity in various raspberry (Rubus spp.) cultivars. Food Chemistry, 132, 1495-1501.

Boehning, A. L., Essien, S. A., Underwood, E. L., Dash, P. K., And Boenning, D. (2018) Cell type-dependent effects of ellagic acid on cellular metabolism, Biomedicine \& Pharmacotherapy, 106, 411-418.

Borges, G., Degeneve, A., Mullen, W., And Crozier, A. (2010). Identification of flavonoid and phenolic antioxidants in black currants, blueberries, raspberries, red currants, and cranberries, Journal of Agricultural and Food Chemistry, 58, 3901-3909.

Buřičová, L., Andjelkovic, M., Cermakova, A., Reblova, Z., Jurcek, O., Kolehmainen, E., and Kvasnicka, F. (2011). Antioxidant capacities and antioxidants of strawberry, blackberry and raspberry leaves. Czech Journal of Food Sciences, 29(2), 181-189.

Cemeroglu, B. (2007). Food analysis. Food Technology Society Publication, 34, 168-171.

Chanyotha, A., Techametheekul, K. W., and Setthayanond, J. (2019). Development and antioxidant activity analysis of bio-cellulose containing Indian gooseberry extract. International
Journal of Advanced Research and Technology, $8(3 \mathrm{~S})$.

Chiang, C. J., Kadoun, H., and Zhou, K. (2013). Phenolic compounds and antioxidant properties of gooseberry as affected by in vitro digestion. LWT-Food Science and Technology, 51(2), 417-422.

Daniel, E. M., Krupnick, A. S., Heur, Y.H., Blinzler, J.A., Nims, R. W., And Stoner, G. D. (1989). Extraction, stability and quantitation of ellagic acid in various fruits and nuts. The Journal of Food Composition and Analysis, 2(4), 338-349.

Geçer, M. K., Akin, M., Gundogdu, M., Eyduran, S. P., Ercisli, S., And Eyduran, E. (2016). Organic acids, sugars, phenolic compounds, and some horticultural characteristics of black and white mulberry accessions from Eastern Anatolia. Canadian Journal of Plant Science, 96, 27-33.

GerçeKçıŏ́lu, R., Bayazit, S., Edizer, Y., and Çekic, Ç. (2009). Performance of some currant (Ribes ssp.) varieties in Tokat ecology. III. National Grape Fruits Symposium, 308-313, Kahramanmaraş.

Gevrenova, R., Badjakov, I., Nikolovac, M., AND Doichinova, I. (2013). Phenolic derivatives in raspberry (Rubus L.) germplasm collection in Bulgaria. Biochemical Systematics and Ecology, 50, 419-427.

Giovanelli, G.,Brambilla, A., Rizzolo,A., AndSinelli, N. (2012). Effects of blanching pre-treatment and sugar composition of the osmotic solution on physico-chemical, morphological and antioxidant characteristics of osmodehydrated blueberries (Vaccinium corymbosum L.). Food Research International. 49, 263-271.

Giusti, M. M., And Wrolstad, R. E. (2001). Characterization and measurement of anthocyanins by UV-visible spectroscopy. Current Protocols in Food Analytical Chemistry, 10(1), F1.2.1-F1.2.13.

Gudej, J., And Tomczyк, M. (2004). Determination of flavonoids, tannins and ellagic acid in leaves from Rubus L. species. Archives of Pharmacal Research, 27(11), 1114-1119.

Gulcin, I., Topal, F., Çakmakci, R., Bilsel, M., Goren, A. C., And Erdogan, U. (2011). Pomological features, nutritional quality, polyphenol content analysis, and antioxidant properties of domesticated and 3 wild ecotype forms of raspberries (Rubus idaeus L.). Journal of Food Science, 76(4), C585-C593.

Gündeşli, M. A., Korkmaz, N., And Okatan, V. (2019). Polyphenol content and antioxidant capacity of berries: A review. International Journal of Agriculture, Forestry and Life Sciences, 3(2), 350-361.

GundoĞDu, M., Kan, T., And CAnan, I. (2016). Bioactive and antioxidant characteristics of blackberry cultivars from East Anatolia. Turkish Journal of Agriculture and Forestry, 40, 344-351.

Kostecka-Gugala, A., Ledwożyw-Smoleń, I., Augustynowicz, J., WyżGolik, G., Kruczek, M., AND KASZYCKI, P. (2015). Antioxidant properties of 
fruits of raspberry and blackberry grown in Central Europe. Open Chemistry, 13, 1313-1325.

Laczkó-Zöldi, E., Komlósi, A., Ülke, T., Fogaras, E., Croitoru, M., Fülöp, I., Domokos, E., Ştefănescu, R., AND VARGA, E. (2018). Extractability of polyphenols from black currant, red currant and gooseberry and their antioxidant activity. Acta Biologica Hungarica, 69(2), 156-169.

Laleh, G. H., Frydoonfar, H., Heidary, R., Jameei, R., AND ZARE, S. (2006). The effect of light, temperature, $\mathrm{pH}$ and species on stability of anthocyanin pigments in four Berberis species. Pakistan Journal of Nutrition, 5(1), 90-92.

Li, H. B., Cheng, K. W., Wong, C. C., FAn, K. W., Chen, F., AND JiAnG, Y. (2007). Evaluation of antioxidant capacity and total phenolic content of different fractions of selected microalgae. Food Chemistry, 102(3), 771-776.

LiaO, J., Zang, J., Yuan, F., Liu, S., Zhang, Y., Li, H., PiaO, Z., AND Li, H. (2015). Identification and analysis of anthocyanin components in fruit color variation in Schisandra chinensis. Journal of the Science of Food and Agriculture, 96, 3213-3219.

Mikulic-Petkovsek, M., Schmitzer, V., Slatnar, A., Stampar, F., and Veberic, R. (2012). Composition of sugars, organic acids, and total phenolics in 25 wild or cultivated berry species. Journal of Food Science, 77(10), C1064-C1070.

Narváez-Cuenca, C. E., Mateus-Gómez, A., And Restreposánchez, L. P. (2014). Antioxidant capacity and total phenolic content of air-dried cape gooseberry (Physalis peruviana L.) at different ripeness stages. Gronomía Colomia, 32(2), 232-237.

OKATAN, V. (2016). The effects of different growing systems on the yield and quality of currant cultivation (Ph.D. thesis). Institute of Science, Süleyman Demirel University, Turkey.

Okatan, V. (2018). Phenolic compounds and phytochemicals in fruits of black mulberry (Morus nigra L.) genotypes from the Aegean region in Turkey. Folia Horticulturae, 30(1), 93-101.

Okatan, V., And Çolak, A. M. (2019). Chemical and phytochemicals content of barberry (Berberis vulgaris L.) fruit genotypes from Sivasli district of Usak province of western Turkey. Pakistan Journal of Botany, 51(1), 165-170.

Pantelidis, G. E., Vasilakakis, M., Manganaris, G. A., and Diamantidis, G. R. (2007). Antioxidant capacity, phenol, anthocyanin and ascorbic acid contents in raspberries, blackberries, red currants, gooseberries and cornelian cherries. Food Chemistry, 102, 777-783.

Pelc, M., Przybye, J. L., Kosakowska, O., Szalacha, E., Szymborska, I., And Węglarz, Z. (2009). Genetic and chemical variability of wild red raspberry (Rubus idaeus L.) growing in Poland. Acta Horticulturae, $860,123-127$.
Pereira, C. C., Da-Silva, E. N., De-Souza, A. O., Vieira, M. A., Ribeiro, A. S., and Cadore, S. (2018). Evaluation of the bioaccessibility of minerals from blackberries, raspberries, blueberries and strawberries. Journal of Food Composition and Analysis, 68, 73-78.

Proteggente, A. R., Pannala, A. S., Paganga, G., Buren, L. V., Wagner, E., Wiseman, S., and Riceevans, C. A. (2002). The antioxidant activity of regularly consumed fruit and vegetables reflects their phenolic and vitamin C composition. Free Radical Research, 36(2), 217-233.

Re, R., Pellegrini, N., Proteggente, A., Pannala, A., Yang, M., And Rice-Evans, C. (1999). Antioxidant activity applying an improved ABTS radical cation decolorization assay. Free Radical Biology \& Medicine, 26, 1231-1237.

Rodriguez-Delgado, M. A., Malovana, S., Perez, J. P., Borges, T., and Garcia-Montelongo, F. J. (2001). Separation of phenolic compounds by high-per-formance liquid chromatography with absorbance and fluorimetric detection. Journal of Chromatography, 912, 249-257.

Rubinskiene, M., Viskelis, P., Jasutiene, I., Viskeliene, R., AND Bobinas, C. (2005). Impact of various factors on the composition and stability of black currant anthocyanins. Food Research International, 38(8-9), $867-871$.

ŞAR, S. (2011). The analysis of the use of certain berries from the perspective of pharmacy and history of medicine, Lokman Hekim Journal, 1(2), 1-6.

Villano, D., Fernández-Pachón, M. S., Moyá, M. L., Troncoso, A. M., and Garcíaparrilla, M. C. (2007). Radical scavenging ability of polyphenolic compounds towards DPPH free radical. Talanta, 71(1), 230-235.

WADA, L., AND Ou, B. (2002). Antioxidant activity and phenolic content of Oregon caneberries. Journal of Agricultural and Food Chemistry, 50(12), 3495-3500.

WANG, S. Y., AND Lin, H. S. (2002). Antioxidant activity in fruits and leaves of blackberry, raspberry, and strawberry varies with cultivar and developmental stage. Journal of Agricultural and Food Chemistry, 48, 140-146.

Zheng, L., Zhou, X., MA, Y., And Guo, M. (2019). Genome-wide identification and characterization of TCP family genes associated with flower and fruit development in Fragaria vesca. Pakistan Journal of Botany, 51(2), 513-519.

Zia-Ul-Haq, M., Riaz, M., De Feo, V., Hawa, Z. E., AND JAAFAR Moga, M. (2014). Rubus fruticosus L.: Constituents, biological activities and health related uses. Molecules, 19, 10998-11029.

Received: 6 February 2020; accepted: 28 February 2020 